\title{
LINEAR AND NONLINEAR ANALYSIS OF THE TRADITIONAL AND DIFFERENTIAL STRENGTH TRAINING
}

\author{
Carlota Torrents ${ }^{1}$, Natàlia Balagué 2 , Jürgen Perl ${ }^{3}$, Wolfgang Schöllhorn ${ }^{4}$ \\ Catalonian National Institute of Physical Education, University of Lleida, Lleida, Spain ${ }^{1}$, Catalonian \\ National Institute of Physical Education, University of Barcelona, Barcelona, Spain², Johannes \\ Gutenberg University, Mainz, Germany ${ }^{3}$,Westphalian Wilhems University, Münster, Germany ${ }^{4}$
}

Carlota Torrents. Professor of Movement Science at the Catalonian National Institute of Physical Education, University of Lleida. Research interests - movement performance.

\begin{abstract}
Training methods are commonly studied using lineal and quantitative research, limiting the possibilities to proof new ways of optimizing the training process. The aim of the study was to compare the classical strength training approach, based on repetitions, with differential training for the improvement of difficulty elements in aerobic gymnastics applying a linear and a nonlinear tool for analyzing the interaction between load and performance.

Two female national standard aerobic gymnasts followed three periods of training (TTa: 5 weeks of traditional training; DT: 8 weeks of differential training; TTb: 5 weeks of traditional training). Load applied to the gymnasts was expressed quantitatively (quantitative load) with an equation including time of execution (t), number of series $(N)$, number of exercises in each series (Rp) and relative intensity, and qualitatively (qualitative load) defining the number of different exercises performed. Performance was defined through 6 tests based on the execution of three different push-ups. Quantitative and qualitative load, the time of execution of the push ups and the time of flight of the jumps were determined weekly during the 17 weeks. The interaction between the load applied to upper limbs and performance of push ups, and the interaction between the load applied to lower limbs and performance of jumps were analyzed using a non-linear metamodel (PerPot) and cross correlations.

Push ups results show that the increase in load quantified qualitatively correlates more positively with the increase in performance than with the increase in load measured quantitatively. This suggests that subjects respond better to an increase in the variation of training stimulus than to an increase in the number of repetitions. Nevertheless, PerPot proposes a reduction in the number of varied exercises in the DT period. Regarding jumping tests, the performance of both subjects remained constant, suggesting that four months of training was not enough to improve the time of flight in experienced gymnasts, or the training methods were not the most adequate.

This study suggests that (1) differential training seems to lead to a greater increase in performance than traditional training, but (2) the same results could be achieved by reducing the number of varied exercises or combining both approaches.
\end{abstract}

Keywords: non-linear metamodel, qualitative load, performance.

\section{INTRODUCTION}

$\mathrm{T}$ he current training methods in many sports are strongly influenced by cybernetics and cognitive theories. The traditional approach of training assumes that the athlete has to know in advance the right or correct movement and try to reproduce it through repetition. The repetitions should provide a basis for creation of fixed responses in a form of motor programs, stereotypes or motor representations which should guide the adaptive behaviour of an athlete. This model is clearly evident in many individual sports, where the situations during competition are apparently always repeated, as in aerobic gymnastics. For many coaches, repetition of exercises is the way to achieve automation. However such relying on the fixed learned responses as a theoretical explanation can not account for the obvious flexibility of motor actions of expert sport performers. Dynamical systems theory gives an original perspective on how these, at first glance, contradictory characteristics of the 
expert performers, namely stability and flexibility, can be attained. New training proposals based on the concept of self-organisation and the individuality of motor actions emerge from this perspective.

The differential training approach (Schöllhorn, 1999) with a different understanding of variability in practice has been compared with traditional methods in many sports (Jaitner, Pfeiffer, 2003; Schönherr, Schöllhorn, 2003; Trockel, Schöllhorn, 2003). Differential training attempts to learn from differences of the motor patterns and claims to prepare the athlete to adapt better to new situations in a shorter time. It can offer a new way of generating changes in coordination, modifying the intrinsic dynamics of the system and providing a new set of experiences for discovering the final response.

The new approaches claim for alternative methods and tools able to capture the qualitative changes produced in motor actions. The nonlinear dynamics framework offers the chance to study such changes and allows the emergence of new ways of optimizing the training process.

The scarce available literature in aerobic gymnastics analyse the muscular and metabolic demands of the sport (Torrents et al., 1999; López et al., 2002) concluding that maximum and mainly explosive strength are the main conditional capacities. Different authors have observed that repetition of analytic exercises is the main approach used to improve performance (Torrents, Balagué, 2001; Gutiérrez, 2002).

In order to study the possibilities of differential training applied to aerobic gymnastics, we analyze the interaction between load and performance, using a linear tool of analysis and a nonlinear one, the PerPot metamodel (Perl, 2001, 2004), as well as a quantitative and a qualitative way to measure the load applied to the athletes.

The aim of the study was a) to compare the classical approach, based on repetitions, with differential training for the improvement of specific difficulty elements of aerobic gymnastics in which muscular strength is a determinant factor; and $b$ ) to observe the differences of a linear and a nonlinear tool for analyzing the interaction between load and performance using two different ways of quantifying load.

\section{MATERIAL AND METHODS}

Subjects. Two female gymnasts of national standard, $20(52 \mathrm{~kg} ; 1.53 \mathrm{~m})$ and 21 years old $(55 \mathrm{~kg} ; 1.60 \mathrm{~m})$ took part in the study and were measured daily during a period of 18 weeks. Accurate control of load and performance parameters was carried out for the case study.

Procedures. Training protocol. The gymnasts trained for 3 hours a day, 6 times a week. Each session was divided in two groups of strength exercises: upper body exercises (related to push-ups) and lower body exercises (related to jumps).

The full training period was divided into 3 sub-periods:

1) 5 weeks of traditional training (TTa), based on high number of repetitions of the same exercises oriented towards getting the correct technique;

2) 8 weeks of differential training (DT) based on varied exercises, as has been already described;

3) 5 weeks of traditional training (TTb), similar to the $1^{\text {st }}$ sub-period.

The load was determined weekly during the whole training period to study its interaction with performance. It was calculated in two ways:

- "Quantitative load" was defined by equation 1 , including time of execution ( $t$ ), number of series $(\mathrm{N})$, number of exercises in each series $(\mathrm{Rp})$ and relative intensity (Irel: percentage of maximum strength and normative scales based on subjective judgment rules -FIG, 2004):

$$
\mathrm{L}=\frac{\mathrm{N} \cdot \mathrm{Rp} \cdot \text { Irel }}{\mathrm{t}} \text { Equation } 1
$$

- "Qualitative load" is defined as the number of different exercises performed.

Testing protocols. Performance was evaluated weekly by means of 6 tests ( 3 of them evaluating the upper body strength with one-arm push-ups and 3 evaluating the lower body strength with jumps):

- One-arm push-ups: performed with the right arm, with the left arm and hinge push-ups. The positions and the required degrees of bending were previously fixed to define valid trials. Subjects had $4 \mathrm{sec}$ to perform a complete push-up and they were asked to do it as fast as possible. The absolute time of execution (flexion and extension movement until recovering the starting position) was evaluated. As the decrease in the execution time will correspond to an increase in the performance, -4 was added to the result of each test to make lower values correspond to worse performance and higher values to better performance. 
- Jumps: Leap jump (jump performing a split sagittal plane - in the air), straddle jump (jump opening legs in the frontal plane) and half turn straddle jump (straddle jump performed after turning $180^{\circ}$ in the air), respecting technical requirements, were performed. Subjects stood off the platform and made a falling step with feet together on to the platform. They had then to perform the jump falling with both feet together and at the same time. The flight time of each jump was measured. One gymnast performed only the leap jump because of choreography requirements.

After a standardized 20 min warm-up, the gymnasts repeated each test three times and the best of them was chosen for the analysis.

A Dynascan-IBV 7.0 force platform was used for collecting the force appliedubiecte $500 \mathrm{~Hz}$ from one arm in the push-ups and from both legs during the jump movements. The sessions were recorded with an $8 \mathrm{~mm}$ video camera.

Data analysis. The PerPot metamodel version 4 was used to study the non-linear interaction between the load and performance. The basic concept of the PerPot metamodel is that of antagonism: each load impulse feeds a strain potential as well as a response potential. These buffer potentials in turn influence the performance potential, where the response potential raises the performance potential and the strain potential reduces the performance potential with a certain delay. The relation between the delays specifies the performance profile. As potential capacities are limited, potential overflows can occur and a reserve profile (difference between strain potential capacity and current strain level) is defined, indicating how close the body is to collapse.

To introduce the load and performance data into the Perpot metamodel, it is normalized to a maximum of 1 .

Cross correlations were also calculated to determine delayed effects between the load and performance.

\section{RESULTS}

One-arm push-ups. Table 1 shows the mean value of the quantitative and qualitative load and the differences between the initial and final performance test values for the push-ups in the 3 training sub-periods in both subjects.

The quantitative load decreased by $22 \%$ (subject 1 ) and by $17 \%$ (subject 2) between the TTa and DT sub-periods and by $19 \%$ and $21 \%$, respectively between the DT and TTb sub-periods. In contrast, qualitative load increased by $82 \%$ and $79 \%$, respectively, between the TTa and DT subperiods and decreases by $87 \%$ and $82 \%$, respectively, between the DT and TTb sub-periods.

Subject 1's performance increased during the TTa sub-period, evaluated by means of the rightarm and hinge push-ups ( 0.34 and $0.562 \mathrm{sec}$, respectively), and decreased in the left-arm test $(0.19 \mathrm{sec})$. During the DT sub-period, it increased by 0.56 , 0.403 and $0.44 \mathrm{sec}$ in right-arm, left-arm and hinge push-up, respectively in all tests and remained rather constant during the TTb sub-period.

Subject 2's performance decreased in the TTa sub-period $(0.18,0.133$ and $0.228 \mathrm{sec}$ respectively for the three push-up tests), increased in the DT sub-period for the push-ups with right and left arm ( 0.306 and $0.52 \mathrm{sec}$, respectively), while it reduced slightly in the hinge push-up test $(0.027 \mathrm{sec})$. In the TTb sub-period, it increased in the left-arm and hinge push-ups $(0.447$ and $0.266 \mathrm{sec}$, respectively) while in the right-arm push-up it remained rather constant.

Both subjects' performance improved more in the DT sub-period than in TTa and TTb.

Subject 1

\begin{tabular}{|l|l|l|l|l|l|}
\hline Periods & Mean QtL & Mean QIL & It-ft RP $(\mathrm{s})$ & It-ft LP $(\mathrm{s})$ & It-ft HP $(\mathrm{s})$ \\
\hline TTa & 2.44 & 27 & 0.34 & -0.19 & 0.562 \\
DT & 1.9 & 150.25 & 0.56 & 0.403 & 0.44 \\
TTb & 1.53 & 19.2 & -0.12 & 0.046 & -0.093 \\
\hline
\end{tabular}

Subject 2

\begin{tabular}{|l|l|l|l|l|l|}
\hline Periods & Mean QtL & Mean QIL & It-ft RP $(\mathrm{s})$ & It-ft LP $(\mathrm{s})$ & It-ft HP $(\mathrm{s})$ \\
\hline TTa & 2.37 & 25 & -0.18 & -0.133 & -0.228 \\
DT & 1.96 & 122.75 & 0.306 & 0.52 & -0.027 \\
TTb & 1.55 & 21.4 & -0.068 & 0.447 & 0.266 \\
\hline
\end{tabular}

Table 1. Mean load for each sub-period and difference in performance between the first and the last pushup tests

Note. Qt1 - quantitative load; QIL - qualitative load; It-ft - result of performance in initial test result of performance of final test; RP - right push-up; LP - left push-up; HP - hinge push-up; TTa - first period of traditional training; DT - period of differential training; $\mathrm{TTb}-$ second period of
traditional training. 
Fig. 1. Performance of right push-up and quantitative load interaction by means of Perpot Metamodel of Subject 1

\begin{tabular}{|l|l|}
\hline File & $\begin{array}{l}\text { Subject 1 } \\
\text { RP QtL }\end{array}$ \\
\hline Dev. Ori & 5.06 \\
\hline Dev. Opt & 0.46 \\
\hline Load $_{\text {mean }}$ & 1.85 \\
\hline Pef $_{\text {mean }}$ & 2.24 \\
\hline D strain & 2.5 \\
\hline D resp & 3.0 \\
\hline
\end{tabular}

Note. RP: Right-arm push-up; QtL: Quantitative Load; Pef: performance; dev.ori: original deviation of data; dev.opt: deviation of optimized data; D strain: delay of strain; D resp: delay of response.

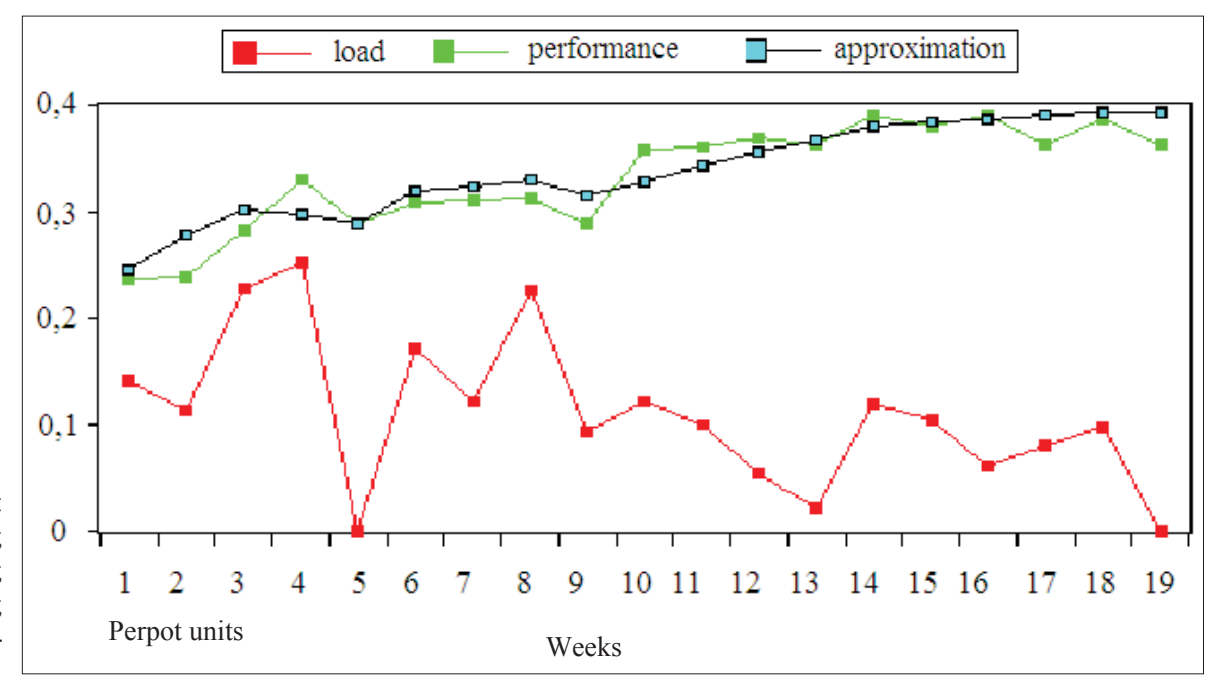

These load-performance interaction results did not consider the delayed effects of load on performance. For this reason, the analyses using the PerPot metamodel and the cross correlation function were applied.

In Fig. 1, the relationship between the performance curve for the right-arm push-up and the quantitative load curve for Subject 1 is shown, using the PerPot metamodel. In Fig. 2, the same relationship is shown using the cross correlation analysis. It was observed that performance increased in the TTa and DT sub-periods, although there was a negative correlation with quantitative load. On the other hand, PerPot detected a positive relationship between delays, as the delay in response was greater than the delay in strain.

Fig. 3 and Fig. 4 show the relationship between qualitative load and performance using the PerPot metamodel and cross correlation analysis. PerPot detected a negative relationship between delays, as the strain delay was greater than the response delay.

Cross correlation analysis showed no significant positive correlation between qualitative load and performance.

Similar results using the PerPot Metamodel were obtained from data from one left-arm pushup and hinge push-up in the same subject. Nevertheless, hinge push-ups underwent a greater change, probably due to the worse initial execution level, as it was a new element for the subjects (see Fig. 5 and 6). Cross correlation analysis showed no significant results, either. Positive correlation occured only when qualitative load and performance correlated.

Fig. 2. Cross correlations between quantitative load and performance of right push-up of Subject 1

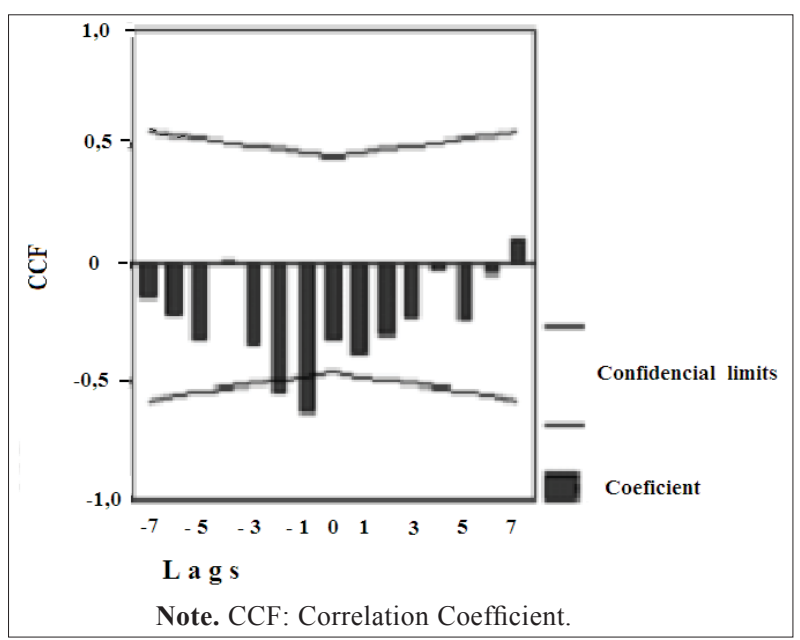

Fig. 4. Cross correlations between qualitative load and performance of right push-up of Subject 1

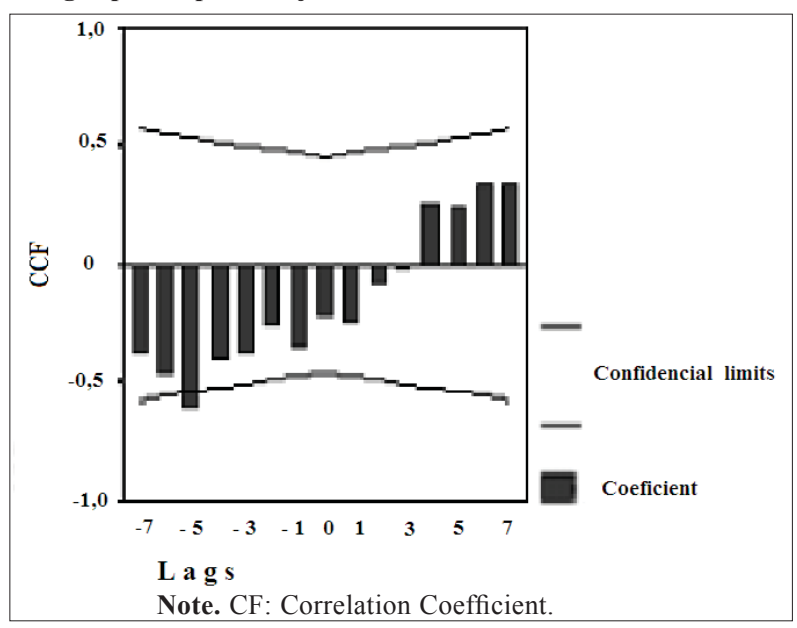

The reserve profile showed similar behaviour in the three push-up exercises. It was positive when the quantitative load was used. On the other hand, an overflow was observed when using qu- 
Fig. 3. Performance of right push-up and qualitative load interaction by means of Perpot Metamodel of Subject 1

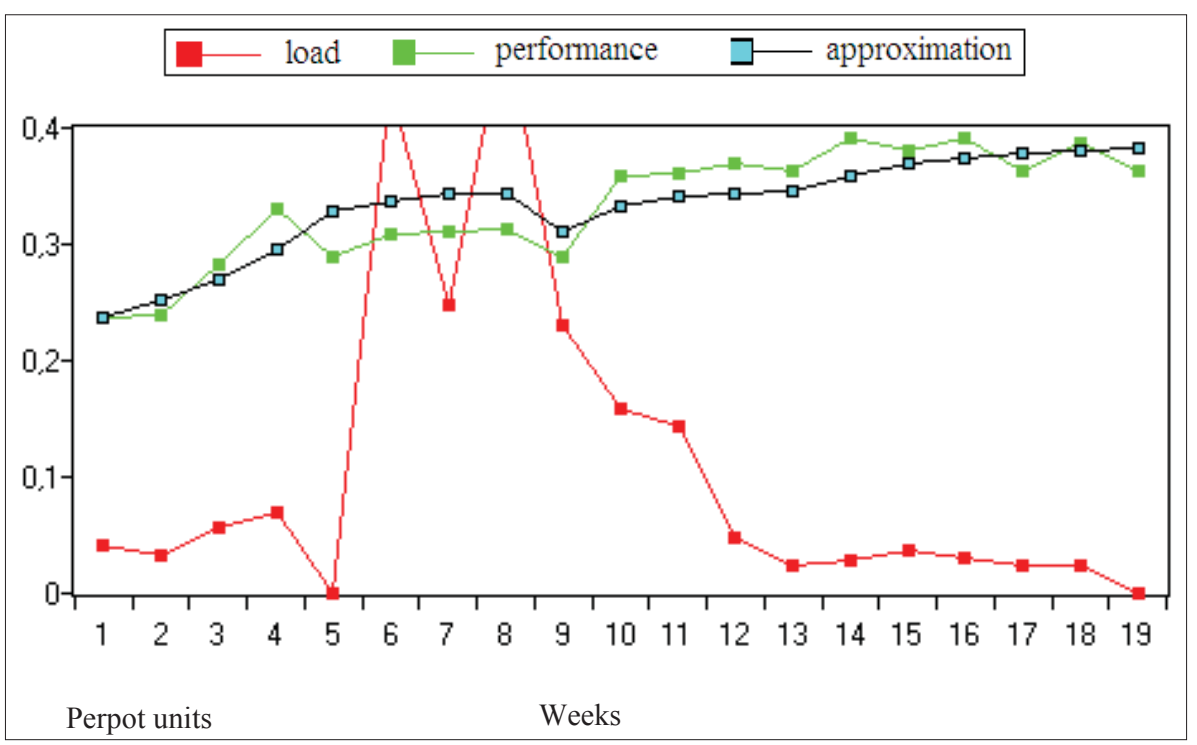

\begin{tabular}{|l|l|}
\hline File & $\begin{array}{l}\text { Subject 1 } \\
\text { RP Q1L }\end{array}$ \\
\hline Dev. Ori & 6.44 \\
\hline Dev. Opt & 1.64 \\
\hline Load $_{\text {mean }}$ & 75.42 \\
\hline Pef $_{\text {mean }}$ & 2.24 \\
\hline D strain & 7.5 \\
\hline D resp & 2.0 \\
\hline
\end{tabular}

Note. RP: Right arm push-up; Q1L: Qualitative Load; Pef: performance; dev.ori: original deviation of data; dev.opt: deviation of optimized data; D strain: delay of strain; D resp: delay of response.

Fig. 5. Quantitative (upper graphs) and qualitative (lower graphs) load with performance of left arm push-up interaction by means of PerPot metamodel

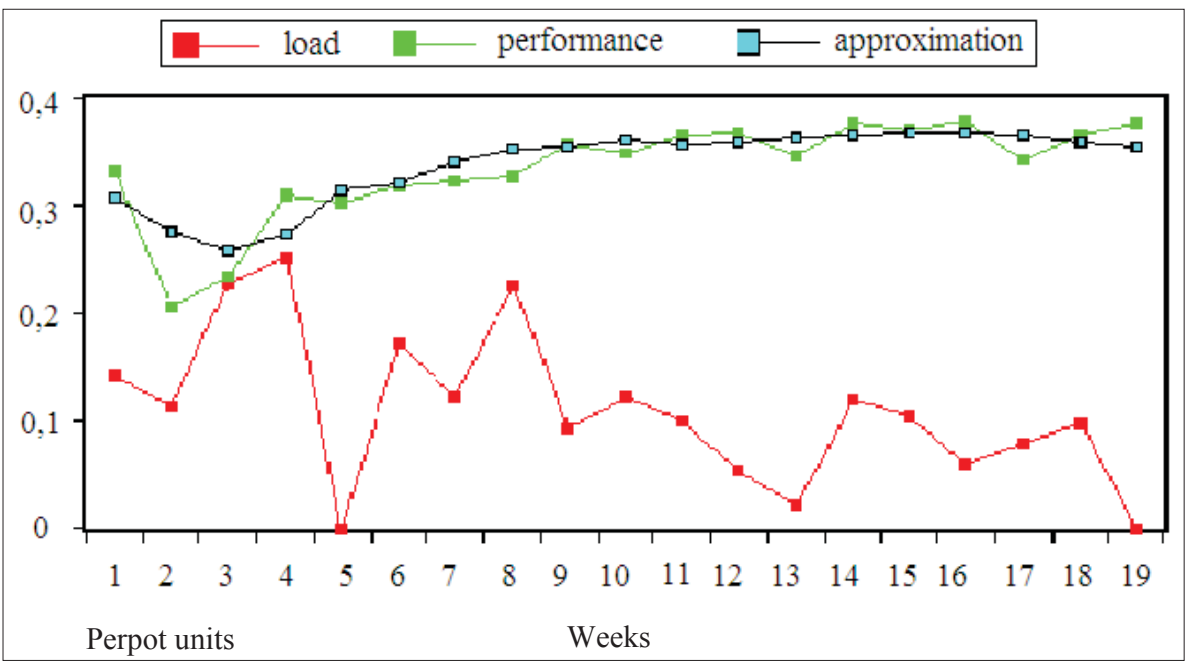

\begin{tabular}{|l|l|}
\hline File & $\begin{array}{l}\text { Subject 1 } \\
\text { LP QtL }\end{array}$ \\
\hline Dev. Ori & 5.18 \\
\hline Dev. Opt & 2.16 \\
\hline Load $_{\text {mean }}$ & 1.85 \\
\hline Pef $_{\text {mean }}$ & 2.29 \\
\hline D strain & 3.5 \\
\hline D resp & 6.0 \\
\hline
\end{tabular}

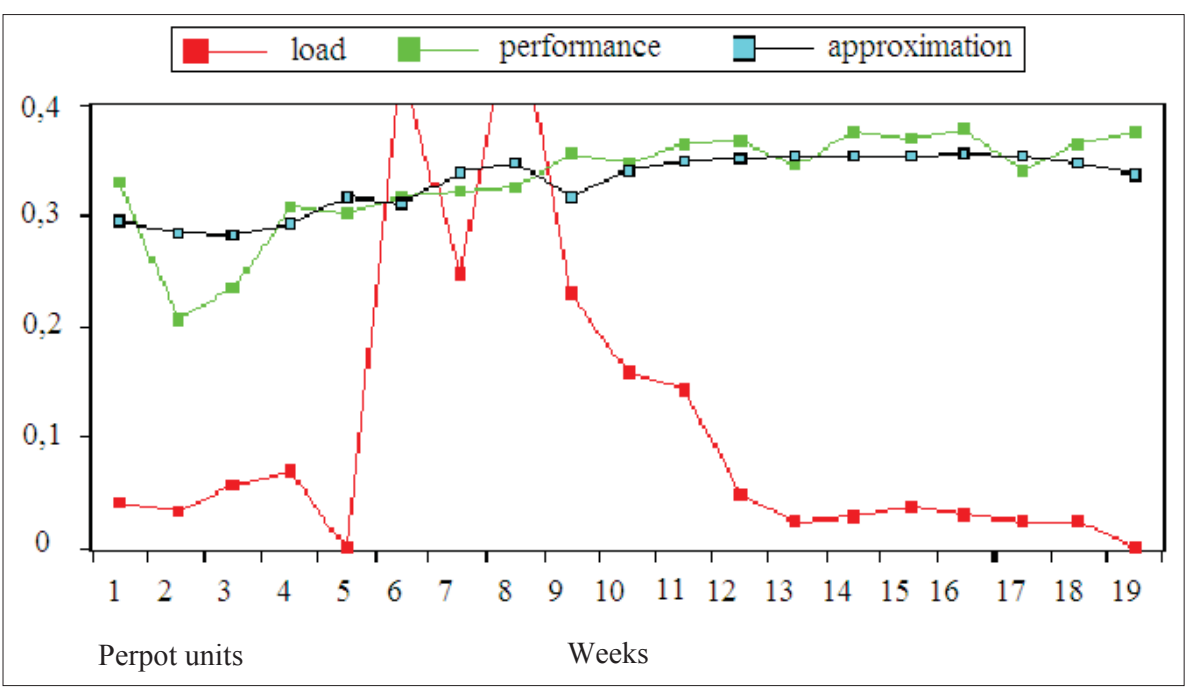

\begin{tabular}{|l|l|}
\hline File & $\begin{array}{l}\text { Subject 1 } \\
\text { LP Q1L }\end{array}$ \\
\hline Dev. Ori & 6.95 \\
\hline Dev. Opt & 4.06 \\
\hline Load $_{\text {mean }}$ & 75.42 \\
\hline Pef $_{\text {mean }}$ & 2.29 \\
\hline D strain & 9.5 \\
\hline D resp & 2.0 \\
\hline
\end{tabular}

Note. LP: Left arm push-up; QtL: Quantitative Load; Q1L: Qualitative Load; Pef: performance; dev.ori: original deviation of data; dev.opt: deviation of optimized data; D strain: delay of strain; D resp: delay of response.

alitative load, detecting a danger of overtraining. For this reason the PerPot metamodel proposed a reduction in qualitative load for the right arm push-up (46.9\%) and for the left arm push-up $(40.7 \%)$.

Table 2 summarizes the PerPot results for Su- 
Fig. 6. Quantitative (upper graphs) and qualitative (down graphs) load with performance of hinge push-up interaction by means of PerPot metamodel

\begin{tabular}{|l|l|}
\hline File & $\begin{array}{l}\text { Subject 1 } \\
\text { HP QtL }\end{array}$ \\
\hline Dev. Ori & 9.61 \\
\hline Dev. Opt & 5.64 \\
\hline Load $_{\text {mean }}$ & 1.85 \\
\hline Pef $_{\text {mean }}$ & 1.20 \\
\hline D strain & 4.0 \\
\hline D resp & 6.0 \\
\hline
\end{tabular}

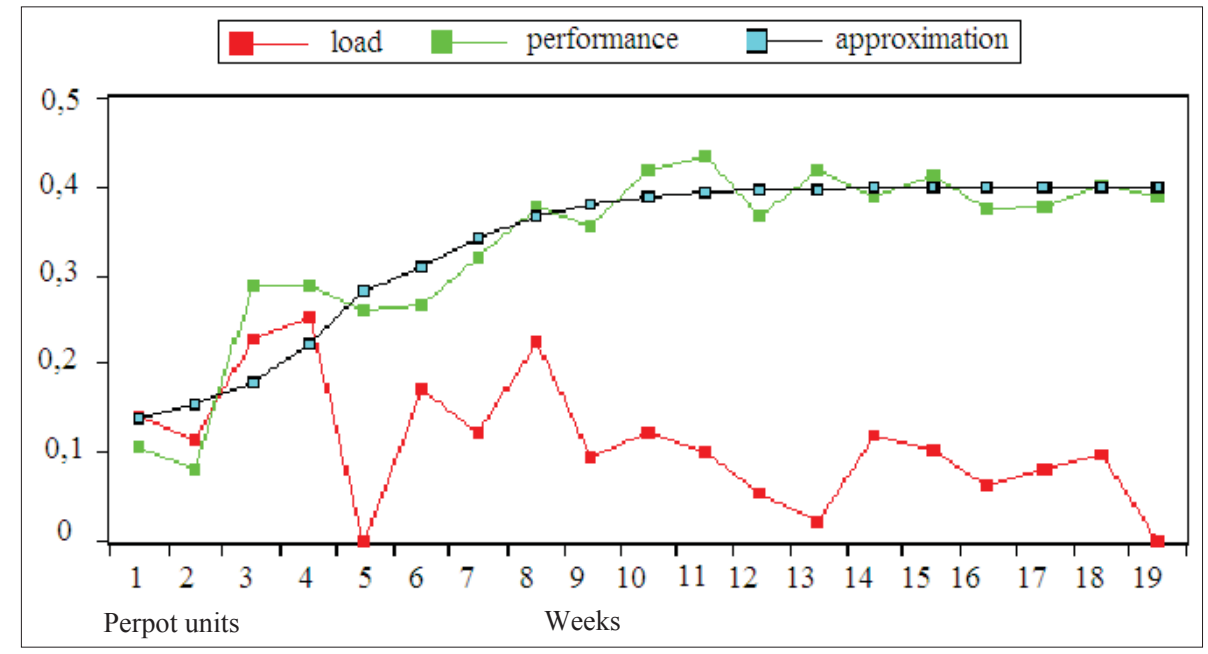

\begin{tabular}{|l|l|}
\hline File & $\begin{array}{l}\text { Subject 1 } \\
\text { HP Q1L }\end{array}$ \\
\hline Dev. Ori & 10.62 \\
\hline Dev. Opt & 6.12 \\
\hline Load $_{\text {mean }}$ & 75.42 \\
\hline Pef $_{\text {mean }}$ & 1.2 \\
\hline D strain & 7.5 \\
\hline D resp & 2.0 \\
\hline
\end{tabular}

Note. HP: Hinge push-up; QtL: Quantitative Load; Q1L: Qualitative Load; Pef: performance; dev. ori: original deviation of data; dev. opt: deviation of optimized data; D strain: delay of strain; D resp: delay of response

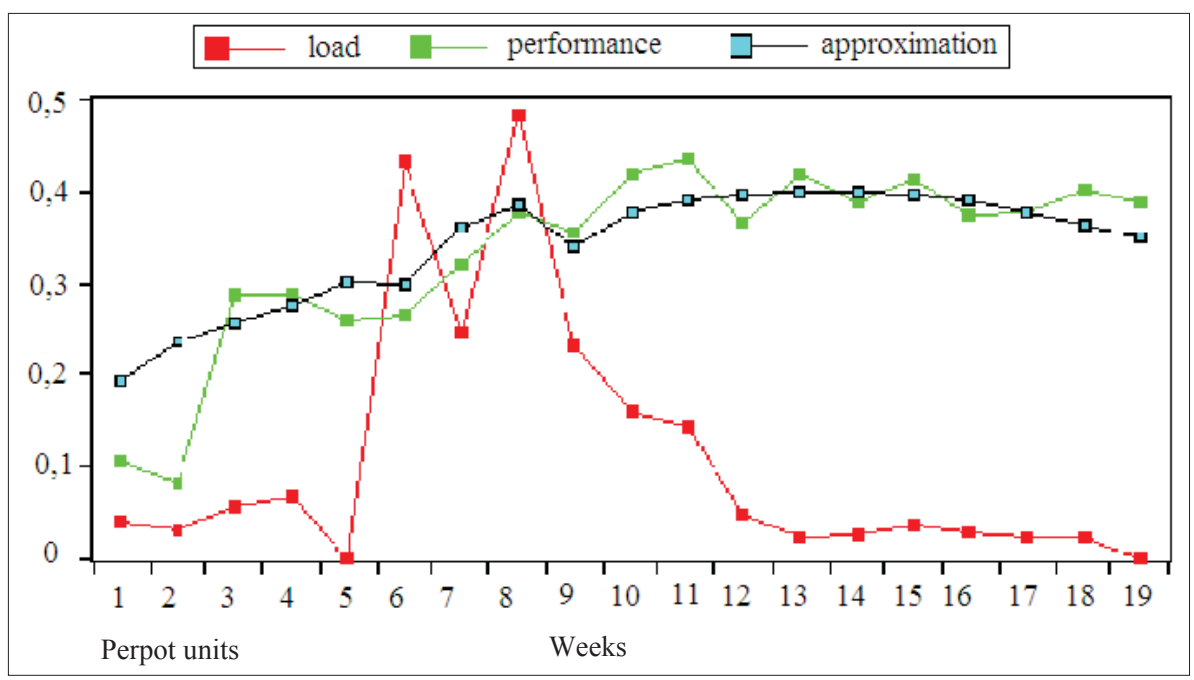

Table 2. Summary of PerPot results of push-ups of Subject 2

Note. RP QtL - right push-up and quantitative load; RP Q1L — right push-up and qualitative load; LP QtL - Left push-up and quantitative load; LP QIL — Left push-up and qualitative load; HP QtL — hinge push-up and quantitative load; HP QIL - Hinge push-up and qualitative load.

\begin{tabular}{|l|l|l|l|l|l|l|}
\hline & RP QtL & RP QIL & LP QtL & LP QIL & HP QtL & HP QIL \\
\hline Mean Load & 1.88 & 67.44 & 1.88 & 67.44 & 1.88 & 67.44 \\
Mean Performance & 2.31 & 2.31 & 2.24 & 2.24 & 1.42 & 1.42 \\
Delay of Strain & 4 & 7 & 1.5 & 6.5 & 4.5 & 5.5 \\
Delay of Response & 7.5 & 2 & 1 & 2 & 8.5 & 2 \\
\hline
\end{tabular}

bject 2. Similar relationships as in Subject 1 were observed between time delays. In this case PerPot also proposed a reduction in qualitative load in the right arm (45.5\%) and left arm (18\%) push-ups.

Cross correlation analysis indicated similar behaviour for Subject 1; positive but not significant correlations was found only between performance and qualitative load.

Jumps. Table 3 shows the mean quantitative and qualitative load values and performance values for each sub-period in both subjects for jumping tests. Performance had not changed significantly in the 18 weeks of training despite the changes in load in the different sub-periods.

Table 4 summarizes the results for both subjects concerning interactions between load and performance using the PerPot metamodel. No significant result is obtained applying cross correlation analysis.

\section{DISCUSSION}

Two subjects were studied following a singlesubject analysis design to compare the effectiveness of differential training with traditional training (Bates et al., 2004). This type of study, besides offering complete information about the gymnasts' responses, fits better with the principles of dynamic 
Subject 1

\begin{tabular}{|l|l|l|l|}
\hline Periods & Mean Qtl & Mean Q1L & It-ft LJ (s) \\
\hline TTa & 2.114 & 26.8 & 0 \\
DT & 1.184 & 45.500 & -0.016 \\
TTb & 0.523 & 19.8 & -0.006 \\
\hline
\end{tabular}

Subject 2

\begin{tabular}{|l|l|l|l|l|l|}
\hline Periods & Mean QtL & Mean Q1L & It-ft LJ (s) & It-ft SJ (s) & It-ft HSJ (s) \\
\hline TTa & 2.69 & 30.4 & -0.028 & -0.027 & 0 \\
DT & 1.310 & 69.250 & -0.030 & -0.090 & -0.040 \\
TTb & 0.505 & 18.2 & -0.026 & -0.023 & -0.006 \\
\hline
\end{tabular}

Subject 1

\begin{tabular}{|l|l|l|}
\hline & LJ QtL & LJ Q1L \\
\hline Mean Load & 1.26 & 28.3 \\
Mean Performance & 0.55 & 0.55 \\
Delay of Strain & 3 & 7.5 \\
Delay of Response & 6 & 2 \\
\hline
\end{tabular}

Subject 2

\begin{tabular}{|l|l|l|l|l|l|l|}
\hline & LJ QtL & LJ Q1L & SJ QtL & SJ Q1L & HSJ QtL & HSJ Q1L \\
\hline Mean Load & 1.47 & 44.58 & 1.47 & 44.58 & 1.47 & 44.58 \\
Mean Performance & 0.55 & 0.55 & 0.58 & 0.58 & 0.54 & 0.54 \\
Delay of Strain & 3 & 2.5 & 3 & 3 & 7 & 4 \\
Delay of Response & 6 & 5 & 6 & 6 & 2 & 7.5 \\
\hline
\end{tabular}

Note. LJ QtL — Leap jump and quantitative load; LJ QIL — Leap jump and qualitative load; SJ QtL — Straddle jump and quantitative load; SJ QtL - Straddle jump and qualitative load; HSJ Qtl - Half turn straddle jump and quantitative load; HSJ QIL — Half turn straddle jump and qualitative load.

Table 3. Mean load for each sub-period and difference of performance between the first and

Note. Qtl - quantitative load; Q1L - qualitative load; It-ft - result of performance of initial test - result of performance of final test; LJ — Leap jump; SJ — Straddle jump; HSJ - Half-turn straddle jump; TTa — first period of traditional training; DT — period of differential training; $\mathrm{TTb}$ - second period of traditional training.

Table 4. Summary of PerPot jumping results for both subjects systems theory than the classical experimental models. The individual adaptive response to training, the dependency on initial conditions and the constant interaction of the gymnasts with the environment are better respected in a single-subject analysis design, rather than averaging data among a sample (Stergiou, 2004) and misrepresenting individual time series (Bouffard, 1993). Moreover, we have replicated the study over two subjects, observing surprising similarities in the behaviour of both of them. This can establish greater validity and generality for results, at least with a population of similar characteristics to the two we have used.

According to the results, the second sub-period, corresponding to the differential training, shows greater improvements in performance evaluated by means of arm push-up tests in both subjects. These results are especially notable in Subject 1, who had worse results in the initial tests. During this DT period, the quantitative load, calculated by the equation quoted including parameters of volume and intensity, decreased, while qualitative load, expressed by the number of different exercises, increased.

The high variability observed when comparing the results of each test session during all the training periods suggests the need to use periodic tests and the analysis of time series instead of the classical comparison between initial and final tests. the last jumping test for both subjects

Considering these results, we can conclude that the differential training method produces greater increases in performance than the classical strength training method based on repetition of the same movements. Similar results have been found comparing the differential training and learning approach with traditional methods in groups of subjects (Jaitner, Pfeiffer, 2003; Schönherr, Schöllhorn, 2003; Trockel, Schöllhorn, 2003). However, these results do not take into account the delayed effects of load on performance, the duration of the different periods, and the natural physiological adaptation processes of the body, presenting delays in response.

The relationship between load and performance using the same data is also analyzed by means of the PerPot metamodel. PerPot detects a better relationship between quantitative load and performance than between qualitative load and performance. Overall, it considers that the quantitative load has been adequate for both subjects. In contrast, it considers that the amount of variations has been excessive and proposes a reduction in the number of variations to prevent overtraining. This response is probably due to the great difference between the numbers of variations proposed in the period of differential training compared to the other two periods of traditional training (TTa: 27, DT: 150,25 and TTb: 19, 2 weekly variations for Subject 1; TTa: 
25, DT: 122,75 and TTb: 21,4 weekly variations for Subject 2). Although greater improvements have been observed in the differential training period, the PerPot indicates that a reduction in the load would allow similar or greater results, preventing overtraining. Overtraining occurs when the capacity of the subject to adapt is exceeded (McKenzie, 1999). For this reason the PerPot detects that qualitative load produces a delay of strain compared to the delay of response. This result did not appear in other studies using the PerPot, probably because load was only evaluated quantitatively (Mester et al., 2000). These results would suggest that an excess of coordinative demands can bring the subject to a state of overtraining.

The same data are also analyzed using cross correlations. In this case, the increase in quantitative load correlates negatively with the increase in performance in the three push-up tests and in both subjects. This analysis shows that the subjects' performance increases more when the training load decreases. In contrast, when load is evaluated qualitatively there are positive correlations between load and performance, showing that the increase in variations increases performance. The first subject shows positive correlations between qualitative load and performance, with a delay of three weeks in the right-arm push-up test and with any delay for the other two arm push-up exercises. Subject 2 shows a similar behaviour as Subject 1, and, despite the lower and non-significant correlations, it is observed that the positive correlation only appears when the load is considered qualitatively. A conclusion is that both subjects respond better to an increase in the variation of training stimulus than to an increase in the number of repetitions. It is important to point out that the load was the same in both forms, the only difference was the way of calculating it (quantitatively or qualitatively).

Regarding jumping tests, the performance of both subjects has remained constant. In Subject 2, a decrease in performance is even observed. This result obscures any clear conclusion about the comparison of both types of training or about the type of load quantification that correlates better with performance.

In beginners, four months of training are possibly enough to improve flight time significantly in all types of jumps. However, experienced gymnasts would probably need a different variable for measuring performance. It is possible that the athletes had already reached their limits, that the training applied has not been adequate or that the variable used for its evaluation (flight time) is not sensitive enough.

\section{CONCLUSION}

Differential training has led to a greater increase in performance in both subjects than traditional training based on repetitions. The increase in load quantified considering the number of variations correlates positively with the increase in performance, while the increase in load quantified through the volume and intensity of the exercises correlates negatively. It has also been observed that the different ways of quantifying load and the different analysis tools can affect the results of the study. The performance is rather variable over the whole period, suggesting that time series analysis is more useful than discrete tests. The number of variations proposed in this study has probably been excessive and same results could be reached by reducing the number of exercises or combining traditional and differential training during the second (DT) sub-period of the study. The effectiveness of this combined training should be further investigated; it would be especially interesting to know when it is more beneficial to apply each type of training. In this context, it would be very helpful to identify a sensitive variable providing information on the state of the athlete in relation to the stability of the process.

\section{REFERENCES}

Bates, B. T., James, C. R., Dufek, J. S. (2004) Single subject analysis. In N. Stergiou (Ed.), Innovative Analyses of Human Movement. Champaign, IL: Human Kinetics. P. $3-28$.

Bouffard, M. (1993) The perils of averaging data in adapted physical activity research. Adapted Physical Activity Quarterly, 10, 371-391.

Gutiérrez, A. (2002). El conocimiento previo de los errores en el aprendizaje de las habilidades gimnásticas del aeróbic deportivo: Doctoral Thesis. Granada: Universidad de Granada.
Jaitner, T., Pfeiffer, M. (2003). Developing jumping strength based on system dynamics principles. In W. I. Schöllhorn, C. Bohn, J. M. Jäger, H. Schaper, M. Alichmann. European Workshop on Movement Science. Mechanics, Physiology, Psychology. Köln: Sport Buch Strauss. P. 75.

López, J., Vernetta, M., de la Cruz, J. C. (2002). Características morfológicas y funcionales del aeróbic deportivo. Apuntes de Educación Física y Deportes, (55), 60-65.

McKenzie, D. C. (1999). Markers of excessive exercise. Canadian Journal of Applied Physiology, 24 (1), 66-73. 
Mester, J., Hartmann, U., Niessen, M., Perl, J. (2000). Time series analyses and metamodels for analyses of physiological adaptation: 5th Annual Congress of the European College of Sport Science. Proceedings. Jyväskylä: University of Jyväskylä.

Perl, J. (2001). PerPot: A metamodel for simulation of load performance interaction. European Journal of Sport Science, (1), 2, 1-13.

Perl, J. (2004). A neural network approach to movement pattern analysis. Human Movement Science, 23, 605-620.

Schöllhorn, W. (1999). Individualität-ein vernachlässsigter parameter? Leistungtsport, 29 (2), 4-11.

Schönherr, T., Schöllhorn, W. I. (2003). Differential learning in basketball. In W. I. Schöllhorn, C. Bohn, J. M. Jäger, H. Schaper, M. Alichmann, European Workshop on
Movement Science. Mechanics, Physiology, Psychology. Cologne: Sport Buch Strauss.

Stergiou, N. (2004). Innovative Analyses of Human Movement. USA: Human Kinetics.

Torrents, C., Balagué, N. (2001). Hábitos de entrenamiento de los competidores espańoles de aeróbic deportivo. VI Simposium de Actividades Gimnásicas. Barcelona: INEFC.

Torrents, C., Peralta, M., Marina, M., Balagué, N. (1999). Valoración de la fuerza del tren inferior aplicada al salto $y$ de la fuerza del tren superior aplicada a las flexiones en gimnastas e instructores de aeróbic: 4art congrés de les ciencies de l'esport, l'educació física i la recreació de l'INEFC de Lleida. Lleida: INEFC.

Trockel, M., Schöllhorn, W. I. (2003). Differential training in soccer. In W. I. Schöllhorn, C. Bohn, J. M. Jäger, H. Schaper, M. Alichmann, European Workshop on Movement Science. Mechanics, Physiology, Psychology. Köln: Sport Buch Strauss.

\title{
TRADICINIO IR DIFERENCIJUOTO JËGOS UGDYMO METODŲ IVERTINIMAS TIESINĖS IR NETIESINĖS ANALIZĖS BŪDAIS
}

\author{
Carlota Torrents $^{1}$, Natàlia Balagué ${ }^{2}$, Jürgen Perl ${ }^{3}$, Wolfgang Schöllhorn ${ }^{4}$ \\ Nacionalinis Katalonijos kūno kultūros institutas, Leidos universitetas, Leida, Ispanija ${ }^{l}$, Nacionalinis \\ Katalonijos kūno kultūros institutas, Barselonos universitetas, Barselona, Ispanija ${ }^{2}$, Johannes \\ Gutenberg universitetas, Maincas, Vokietija ${ }^{3}$,Vestfalijos Vilhelmo universitetas, Miunsteris, Vokietija ${ }^{4}$
}

\section{SANTRAUKA}

Treniruotès metodų efektyvumui vertinti dažniausiai taikomi tiesinės ar kiekybinės analizès metodai, bet jie dažnai neleidžia atskleisti vertinamų treniruotès metodų naudingumo ir tikslingumo, sprendžiant treniruotès vyksmo optimizavimo problemas. Šios studijos tikslas buvo tiesinès ir netiesinès analizès metodais palyginti jègos ugdymo efektyvumą taikant tradicini jègos ugdymo ciklą — parenkant tinkamą pratimo kartojimų kieki ir diferencijuoto jègos lavinimo metodą — didinant pratimo elementų sudètinguma.

Dvi moterys, Ispanijos nacionalinės aerobikos rinktinès narès, atliko suplanuotus tris treniruotės mezociklus taikant šiuos metodus: TTa - penkių savaičių tradicini jègos lavinimo; DT — aštuonių savaičių diferencijuotą jëgos lavinimo; TTb - penkių savaičių tradicini jẻgos lavinimo. Per pratybas gimnasčių atliekamas krūvis buvo kiekybiškai išreiškiamas (kiekybinis krūvis) lygtimi, kartu įvertinant pratimų atlikimo trukmę (t), atliktų seriju skaičių (N), kiekvienos serijos pratimų skaičiu (Rp) ir santykinį intensyvumą. Atliktas ir kokybinis vertinimas (kokybinis krūvis) nustatant skirtingu pratimu skaičių. Gimnasčiu specialusis darbingumas buvo vertinamas atliekant šešis testus, kuriuos sudare trys skirtingi atsispaudimai. Kiekybinis ir kokybinis treniruotès krūviai, atsispaudimų ir lékimo fazės trukmè atliekant šuolius buvo registruojami kas savaitę (visas 17 savaičiu). Ryšys tarp rankų ir pečiu lanko raumenimis atlikto treniruotès krūvio ir atsispaudimu, tarp atlikto kojų raumenims treniruotès krūvio ir šuolių buvo tiriamas naudojant netiesini metamodeli (PerPot) ir Kros-koreliacinès analizès metodą.

Atsispaudimų i̇verčiai parodè, kad kokybinis treniruotès krūvio didinimas reikšmingiau koreliavo su specialiojo darbingumo padidèjimu nei kiekybiškai išreikštas padidejimas. Vadinasi, tirtų asmenu jègos rodiklius daugiau veikia atliekamų pratimų ivvairové negu pratimo kartojimų kiekio didejjimas. PerPot rodo, kad tikslinga sumažinti atliekamų pratimų kieki diferencijuoto jègos ugdymo mezociklu. Tyrimo metu reikšmingai nepasikeite abieju tiriamuju šoklumas, ir tai gali reikšti, kad šie keturi mėnesiai buvo per trumpas laikas arba kad taikyti treniruotès metodai nebuvo tinkamiausi.

Galima daryti išvadas: 1) taikant diferencijuoto jègos ugdymo metodą labiau pagerèja specialusis darbingumas nei taikant tradicini jègos ugdymo metodą; 2) to paties rezultato galima pasiekti sumažinant atliekamų pratimų kieki arba derinant abu metodus.

Raktažodžiai: netiesiniai metamodeliai, kiekybinis krūvis, darbingumas.

Gauta 2007 m. birželio 13 d.

Received on June 13, 2007

Priimta $2007 \mathrm{~m}$. rugsèjo $19 \mathrm{~d}$.

Accepted on September 19, 2007

\author{
Carlota Torrents \\ Catalonian National Institute of Physical Education, \\ University of Lleida \\ (Nacionalinis Katalonijos kūno kultūros institutas, \\ Leidos universitetas) \\ Pda. Caparrella, s/n \\ 25192 Lleida \\ Spain (Ispanija) \\ E-mail carlotat@inefc.es
}

